\title{
HERBICIDE WEED CONTROL - INDUCED DIFFERENTIAL TOLERANCE AND PRODUCTIVITY IN COWPEA PLANTS
}

\author{
RESPOSTA DIFERENCIAL DE TOLERÂNCIA E PRODUTIVIDADE DE \\ FEIJÃO-CAUPI INDUZIDA POR HERBICIDAS PARA CONTROLE DE \\ PLANTAS DANINHAS
}

\section{Fernando Ramos de SOUZA ${ }^{1}$; Ernandes Silva BARBOSA ${ }^{2}$; Lucas César MARTINS ${ }^{3}$; Junior BORELLA ${ }^{4}$; Aroldo Ferreira Lopes MACHADO ${ }^{5}$}

1. Doutorando PPG Fitotecnia, Universidade Federal Rural do Rio de Janeiro - UFRRJ, Seropédica, RJ, Brasil. 2. Mestrando PPG Fitotecnia, Universidade Federal Rural do Rio de Janeiro - UFRRJ, Seropédica, RJ, Brasil. 3. Graduando em Agronomia, Universidade Federal Rural do Rio de Janeiro - UFRRJ, Seropédica, RJ, Brasil. 4. Professor Instituto de Ciências Biológicas, Universidade Federal do Rio Grande - FURG, Rio Grande, RS, Brasil. borellaj@gmail.com. 5. Professor do Departamento de Fitotecnia, Universidade Federal Rural do Rio de Janeiro - UFRRJ, Seropédica, RJ, Brasil. aroldomachado@yahoo.com.br

\begin{abstract}
The use of herbicides is a represents an efficient way to control the infesting plant population, since it is associated with low operational cost, and it does not demand large amounts of labour. An obstacle to growing cowpea (Vigna unguiculate) is the absence of herbicides registered for this crop. The objective of this work was to evaluate the tolerance of cowpea to herbicides. The experiment was carried out in a randomised block with treatment controls with and without weeding, Bentazon ( $\left.720 \mathrm{~g} \mathrm{ha}^{-1}\right)$, Fluazifop-p-butyl $\left(250 \mathrm{~g} \mathrm{ha}^{-1}\right)$, Fomesafen and a tank mix between Fluazifop-p-butyl + Fomesafen $\left(250+187.5 \mathrm{~g} \mathrm{ha}^{-1}\right)$ with treatment replicates. The herbicides were applied on vegetative (V3 - stage) cowpea plants using a $\mathrm{CO}_{2^{-}}$ pressurised backpack sprayer with four spray tips TT 110.02 operating at a pressure of 2.5 bar and applying 240 litres of syrup per hectare. The cultivar BRS Guariba, with five planting lines per plot, was tested with the three central lines of the useful area, scoring $0.5 \mathrm{~m}$ of the ends. The species Oxalis latifolia was difficult to control. The Fluazifop-p-butyl + Fomesafen mixture presented better control of weeds. The herbicides caused phytotoxicity to cowpea and reduced leaf area and dry mass. The productivity of the crop was affected due to the low control of weeds. It was concluded that the cowpea presented differential tolerance to the herbicides tested doses.
\end{abstract}

KEYWORDS: Chemical Control. Herbicide tolerance. Productivity. Vigna unguiculata.

\section{INTRODUCTION}

The cowpea (Vigna unguiculata L. Walp), from the Fabaceae family, was first documented in Southeast Asia (PADULOSI, 1997). The plants have a short life cycle (ranging from 60 to 80 days), low water and nutrient requirements, and it is reputed to be the most drought- and heat-resistant crop in semi-arid regions where other food legumes do not perform as well (SIMPLICIO; GONÇALVES; DUARTE, 2016). Such characteristics make the cowpea the focus of active breeding research for combating poverty in developing countries in order to support millions of people in the tropics and subtropics worldwide (HALL, 2012). In Brazil, most cowpea productivity is concentrated on the North and Northeast due to elevated temperatures and water scarcity, making this crop the main source of plant protein to feed the needy population (FREITAS, 2014). This makes the species an interesting model for investigating the basis of tolerance adaptation.

Currently, with the development of cultivars with erect plant architecture, which makes possible the mechanisation of the crop, the cowpea has aroused the interest of large producers in the centralwest region in Brazil, mainly in the state of Mato Grosso (FREIRE FILHO; ROCHA; SILVA, 2011). However, for crops in large areas, one of the problems faced by farmers is the need to adopt an efficient and low-cost weed management program, since weed growth in cowpea can result in losses of yield of up to $95 \%$ (FREITAS; MEDEIROS; GRANGEIRO, 2009; $\quad$ FAYINMINNU; ADESIYAN; SOSANYA, 2010; GARKO; MOHAMMED; FULANI., 2016).

The use of herbicides represents an efficient way to control weed plant population, due to the low operational cost, and because it does not demand large amounts of labour (MONTEIRO; CHAGAS JUNIOR; REIS, 2012). However, the main obstacles to the use of chemical control for this crop is the absence of registered products (SIZENANDO FILHO; ALMEIDA; PINTO, 2013). Therefore, it is common the use of registered products for soybeans and common bean in cowpea, considering that the 
Herbicide weed...

pests, diseases, and weeds that occur in these cultures are similar (MONTEIRO; CHAGAS JUNIOR; REIS, 2012). However, there are currently no previous studies about the impacts of the herbicides on plant development.

In many cases, the use of herbicides has caused several problems to the farmers due to the phytotoxicity to plants, causing the stoppage of growth and consequently reduction in crop productivity (FREITAS; MEDEIROS; GRANGEIRO, 2009). It can also lead to the death of plants (MESQUITA; FREITAS; FREIRE FILHO, 2017). On the other hand, increased food production is a high priority in many parts of the world, and this need cannot be met without the use of indispensable agricultural inputs, such as pesticides (FAYINMNNU et al., 2010). Given the importance of the growing cowpea cultivation in the Southeast and the use of non-registered products for the weed control of cowpea plants, the aim of this study was to evaluate the tolerance, development, and productivity of cowpea plants subjected to postemergence herbicides application.

\section{MATERIAL AND METHODS}

\section{Plant material and growth conditions}

The experiment was carried out in field, (geographical coordinates: $22^{\circ} 45^{\prime} 08.62^{\prime}, \mathrm{S}$ and 4340'28.50', W - Seropédica/RJ), at an altitude of $27 \mathrm{~m}$ where the Köppen Aw climate classification type predominates, with wet summers and dry winters. The average annual temperature was about $23.9^{\circ} \mathrm{C}$ and the average precipitation was $1,213 \mathrm{~mm}$ in the year 2015 (INMET, 2015). The soil, characterized as Acrisol, was collected at depths up to $40 \mathrm{~cm}$ and submitted to (granulometric) chemical and physical analyses as follows: $\mathrm{pH}\left(\right.$ in $\left.\mathrm{H}_{2} \mathrm{O}\right)=5.5$; Al exchange $\left(\right.$ cmolc $\left.\mathrm{dm}^{-3}\right)=0.15 ; \mathrm{Ca}+\mathrm{Mg}$ (cmolc $\left.\mathrm{dm}^{-3}\right)=6.3 ; \mathrm{P}\left(\mathrm{mg} \mathrm{dm}^{-3}\right)=20 ; \mathrm{K}\left(\mathrm{mg} \mathrm{dm}^{-3}\right)=28.5$; $\mathrm{V}(\%)=69.6 ; \mathrm{m}(\%)=2.91 ;$ Sum of bases $(\%)=$ 6.48 .

Plants of cowpea (Vigna unguiculate L. Walp) and cv. BRS Guariba were obtained from seeds. The experimental set up consisted of five planting lines per plot, tested with the three central lines of the useful area, scoring $0.5 \mathrm{~m}$ of the ends with plenty density of 12 plants per linear $\mathrm{m}^{-1}$. The seeds were inoculated $24 \mathrm{~h}$ before sowing with Bradyrhizobium sp. strain BR 3262 (5 $\mathrm{g} \mathrm{Kg}^{-1}$ of seeds).

The treatments were initiated with plants of cowpea at vegetative stage (V3), 21 days after sowing and consisted of the application of herbicides: Bentazon (720 $\mathrm{g} \mathrm{ha}^{-1}$ ), Fluazifop-p-butyl
SOUZA et al.

(250 $\left.\mathrm{g} \mathrm{ha}^{-1}\right)$, Fomesafen $\left(187,5 \mathrm{~g} \mathrm{ha}^{-1}\right)$, mix of Fluazifop-p-butyl + Fomesafen $\left(250+187,5 \mathrm{~g} \mathrm{ha}^{-1}\right)$, and two control treatments without herbicide: with and without weeding. For herbicide application, a $\mathrm{CO}_{2}$ pressurised spool was used, operating at a pressure of 2.5 bars, and previously calibrated to apply $240 \mathrm{~L}$ of syrup per ha. The spray bar was equipped with four model TT 110.02 tips. The application was performed in the morning, with a recorded temperature of $20^{\circ} \mathrm{C}$, relative humidity of $73 \%$, and minimum and maximum wind speed of 2.4 and $4.18 \mathrm{~km} / \mathrm{h}$, respectively. For the weed control, the first weeding was performed at 20 DAA (days after application), followed by a second weeding 15 thereafter.

\section{Phytosociology analysis}

Two phytosociological evaluations were carried out according to Carvalho (2011). The first one was evaluated one day before the application of the herbicides and the second one, 30 days after the application. For the evaluations, in each experimental plot, two samplings were established by means of randomly launching a metal square measuring $0.30 \mathrm{~m}$ on the sides. At each launch, the weeds shoot inside the square were harvested, and the individuals were counted and identified by family, genus, and species. The samples were then placed in an oven with forced air ventilation at $65^{\circ} \mathrm{C}$ for 72 hours until reaching a constant mass. Subsequently, the samples were weighed on a precision scale to quantify the dry matter.

\section{Phytotoxicity analysis}

Phytotoxicity analysis of plants was performed at 7, 14, 21, and 28 days after application of the herbicides (DAA) by visual evaluation of intoxication of cowpea plants according to the modified EWRC scale (FRANS, 1972). The herbicide efficacy was evaluated for weed control with percentages of monocotyledonous and cyperaceous weeds (FE), eudicotyledonous (FL), and total control (TOTAL). The absence of control was attributed $0 \%$ and total control $100 \%$, evidenced by the death of the plants.

\section{Growing parameters}

Cowpea plants at the reproductive stage were used to determine leaf area index and dry weight accumulation. Leaf area was measured in a portable leaf area meter model LI - 3000C (LICOR, USA). Afterwards, plants were dried in an oven at $65^{\circ} \mathrm{C}$ with forced air ventilation until getting a dry weight constant. 


\section{Productivity analysis}

At the end of the reproductive stage, ten plants were randomly chosen per line plot to evaluate productivity: number of pods per plant (NPP), length of the pods (LP), number of grains per pod (NGP), and weight of 100 grains (WG). Crop productivity (PROD) was measured from the total sample of grains harvested in the experimental area of the plot.

\section{Statistical analysis}

Each treatment consisted of four replicates in a block randomised design. The data were analysed by analysis of variance (ANOVA). When $F$ was significant, the treatment means were compared by the Tukey test $(p \leq 0.05)$, except for the phytosociological ones. Statistical analyses were performed using the Sisvar 5.6 statistical software program.

\section{RESULTS AND DISCUSSION}

The phytosociology evaluation performed before the application of herbicides showed the presence of 15 weed species. Among the species, 12 belong to the class of eudicotyledonous (Table 1).

Table 1. Weed species in the experimental area before herbicide application. Species density (De.I.); Relative density (De.R.); Relative frequency (Fr.R.); Relative dominancy (Do.R.); Relative importance (IR).

\begin{tabular}{|c|c|c|c|c|c|c|}
\hline Treatment & Weed species & $\begin{array}{l}\text { De.I } \\
\left(\mathrm{m}^{2}\right)\end{array}$ & $\begin{array}{l}\text { De.R } \\
(\%)\end{array}$ & $\begin{array}{l}\text { Fr.R } \\
(\%)\end{array}$ & $\begin{array}{l}\text { Do.R } \\
(\%)\end{array}$ & $\begin{array}{l}\text { IR } \\
(\%)\end{array}$ \\
\hline \multirow{7}{*}{ Without weeding } & Panicum maximum Jacq. & 1830.56 & 81.91 & 16.67 & 63.25 & 53.94 \\
\hline & Oxalis latifolia & 205.56 & 9.20 & 16.67 & 8.53 & 11.47 \\
\hline & Amaranthus spp. & 150.00 & 6.71 & 16.67 & 7.85 & 10.41 \\
\hline & Cyperus rotundus $\mathrm{L}$. & 26.39 & 1.18 & 16.67 & 7.60 & 8.48 \\
\hline & Euphorbia heterophylla $\mathrm{L}$. & 1.39 & 0.06 & 4.17 & 3.17 & 2.47 \\
\hline & Phyllanthus tenellus & 1.39 & 0.06 & 4.17 & 2.97 & 2.40 \\
\hline & Other species & 19.44 & 0.87 & 25.00 & 6.64 & 10.84 \\
\hline \multirow{6}{*}{ Bentazon } & Panicum maximum Jacq. & 998.61 & 56.88 & 15.38 & 46.64 & 39.63 \\
\hline & Jaegeria hirta & 351.39 & 20.02 & 26.92 & 40.34 & 29.09 \\
\hline & Oxalis latifolia & 326.39 & 18.59 & 15.38 & 2.53 & 12.17 \\
\hline & Cyperus rotundus L. & 55.56 & 3.16 & 15.38 & 9.58 & 9.38 \\
\hline & Euphorbia heterophylla L. & 1.39 & 0.08 & 3.85 & 0.17 & 1.36 \\
\hline & Other species & 22.22 & 1.27 & 23.08 & 0.75 & 8.37 \\
\hline \multirow{6}{*}{ Fluazifop-p-butyl } & Panicum maximum Jacq. & 1101.39 & 69.37 & 14.81 & 75.97 & 53.38 \\
\hline & Amaranthus spp. & 262.50 & 16.53 & 14.81 & 14.78 & 15.38 \\
\hline & Oxalis latifolia & 170.83 & 10.76 & 14.81 & 3.67 & 9.75 \\
\hline & Cyperus rotundus $\mathrm{L}$. & 20.83 & 1.31 & 14.81 & 5.29 & 7.14 \\
\hline & Euphorbia heterophylla $\mathrm{L}$. & 1.39 & 0.09 & 3.70 & 0.02 & 1.27 \\
\hline & Other species & 30.847 & 1.943 & 37.04 & 0.27 & 13.08 \\
\hline \multirow{9}{*}{ Fomesafen } & Panicum maximum Jacq. & 834.72 & 71.72 & 15.38 & 51.98 & 46.36 \\
\hline & Cyperus rotundus L. & 38.89 & 3.34 & 15.38 & 30.88 & 16.54 \\
\hline & Oxalis latifolia & 168.06 & 14.44 & 15.38 & 11.72 & 13.85 \\
\hline & Amaranthus spp. & 88.89 & 7.64 & 15.38 & 3.96 & 9.00 \\
\hline & Euphorbia heterophylla $\mathrm{L}$. & 4.17 & 0.36 & 7.69 & 0.40 & 2.82 \\
\hline & Portulaca oleracea & 2.78 & 0.24 & 3.85 & 0.02 & 1.37 \\
\hline & Brachiaria decumbens & 1.39 & 0.12 & 3.85 & 0.06 & 1.34 \\
\hline & Phyllanthus tenellus & 1.39 & 0.12 & 3.85 & 0.02 & 1.33 \\
\hline & Other species & 23.611 & 2.029 & 19.23 & 0.938 & 7.399 \\
\hline \multirow{6}{*}{ Fluazifop-p-butyl + Fomesafen } & Panicum maximum Jacq. & 1109.72 & 81.70 & 20.00 & 86.53 & 62.74 \\
\hline & Oxalis latifolia & 156.94 & 11.55 & 20.00 & 1.82 & 11.12 \\
\hline & Cyperus rotundus $\mathrm{L}$. & 23.61 & 1.74 & 15.00 & 9.72 & 8.82 \\
\hline & Amaranthus spp. & 47.22 & 3.48 & 20.00 & 0.72 & 8.06 \\
\hline & Commelina benghalensis & 1.39 & 0.10 & 5.00 & 0.39 & 1.83 \\
\hline & Other species & 19.44 & 1.43 & 20.00 & 0.83 & 7.42 \\
\hline
\end{tabular}

Other species - Mentha rotundifolia, Nicandra physalode. 
The major occurrence of species in all treatments was Panicum maximum, Oxalis latifolia, and Amaranthus spp (Table 1). According to Carvalho (2011), phytosociology evaluation provides useful information about which weed species represents the major constraint to the crops in agroecosystems. In the experiment with cowpea, before the application of herbicides, the species Panicum maximum showed great IR (Table 1), characterising this species with highly competitive potential against cowpea plants.
The use of herbicides induced changes in the weed community after 30 days of application (Table 2) by controlling weed plants. At the second phytosociology evaluation, the species with high IR were Panicum maximum Jacq (without weeding), Panicum maximum Jacq. (Bentazon treated), Oxalis latifolia (Fluazifop-p-butyl), Panicum maximum Jacq (Fomesafen), and Cyperus rotundus L. (mix of Fomesafen + Fluazifop-p-butyl).

Table 2. Weed species in the experimental area 30 days after herbicide application. Species density (De.I.); Relative density (De.R.); Relative frequency (Fr.R.); Relative dominancy (Do.R.); Relative importance (IR).

\begin{tabular}{|c|c|c|c|c|c|c|}
\hline Treatment & Weed species & $\begin{array}{l}\text { De.I. } \\
\left(\mathrm{m}^{2}\right)\end{array}$ & $\begin{array}{l}\text { De.R. } \\
(\%)\end{array}$ & $\begin{array}{l}\text { Fr.R. } \\
(\%)\end{array}$ & $\begin{array}{l}\text { Do.R. } \\
(\%)\end{array}$ & $\begin{array}{l}\text { IR } \\
(\%)\end{array}$ \\
\hline \multirow{10}{*}{ Without weeding } & Panicum maximum Jacq. & 458.33 & 68.75 & 18.60 & 83.47 & 56.94 \\
\hline & Oxalis latifolia & 63.89 & 9.58 & 16.28 & 0.87 & 8.91 \\
\hline & Jaegeria hirta & 54.17 & 8.13 & 9.30 & 2.29 & 6.57 \\
\hline & Cyperus rotundus $\mathrm{L}$. & 16.67 & 2.50 & 9.30 & 3.75 & 5.18 \\
\hline & Galinsoga quadriradiata & 31.94 & 4.79 & 6.98 & 3.15 & 4.97 \\
\hline & Emilia sonchifolia & 9.72 & 1.46 & 9.30 & 0.29 & 3.68 \\
\hline & Axonopus affinis & 6.94 & 1.04 & 4.65 & 2.89 & 2.86 \\
\hline & Commelina benghalensis & 5.56 & 0.83 & 6.98 & 0.31 & 2.71 \\
\hline & Brachiaria plantaginea & 6.94 & 1.04 & 4.65 & 0.83 & 2.17 \\
\hline & Other species & 12.50 & 1.88 & 13.95 & 2.16 & 5.99 \\
\hline \multirow{7}{*}{ Bentazon } & Panicum maximum Jacq. & 515.28 & 72.46 & 22.86 & 96.37 & 63.90 \\
\hline & Oxalis latifolia & 122.22 & 17.19 & 22.86 & 0.80 & 13.62 \\
\hline & Jaegeria hirta & 36.11 & 5.08 & 17.14 & 0.43 & 7.55 \\
\hline & Cyperus rotundus L. & 20.83 & 2.93 & 14.29 & 0.82 & 6.01 \\
\hline & Brachiaria plantaginea & 6.94 & 0.98 & 8.57 & 0.38 & 3.31 \\
\hline & Cenchrus echinatus & 4.17 & 0.59 & 5.71 & 1.04 & 2.45 \\
\hline & Other species & 5.56 & 0.78 & 8.57 & 0.16 & 3.17 \\
\hline \multirow{8}{*}{ Fluazifop-p-butyl } & Jaegeria hirta & 180.56 & 30.30 & 14.58 & 49.15 & 31.35 \\
\hline & Oxalis latifolia & 188.89 & 31.70 & 14.58 & 4.76 & 17.01 \\
\hline & Cyperus rotundus L. & 25.00 & 4.20 & 14.58 & 24.54 & 14.44 \\
\hline & Bidens Pilosa & 120.83 & 20.28 & 8.33 & 9.54 & 12.72 \\
\hline & Euphorbia irta L. & 9.72 & 1.63 & 6.25 & 1.33 & 3.07 \\
\hline & Emilia sonchifolia & 5.56 & 0.93 & 6.25 & 1.48 & 2.89 \\
\hline & Phyllanthus tenellus & 11.11 & 1.86 & 6.25 & 0.17 & 2.76 \\
\hline & Other species & 59.72 & 9.87 & 37.74 & 9.20 & 18.94 \\
\hline \multirow{6}{*}{ Fomesafen } & Panicum maximum Jacq. & 295.83 & 69.84 & 27.59 & 80.62 & 59.35 \\
\hline & Cyperus rotundus $\mathrm{L}$. & 48.61 & 11.48 & 24.14 & 10.19 & 15.27 \\
\hline & Oxalis latifolia & 51.39 & 12.13 & 20.69 & 0.71 & 11.18 \\
\hline & urucloa spp & 5.56 & 1.31 & 6.90 & 7.22 & 5.14 \\
\hline & Euphorbia irta L. & 11.11 & 2.62 & 6.90 & 0.25 & 3.26 \\
\hline & Other species & 11.11 & 2.62 & 13.79 & 1.01 & 5.81 \\
\hline \multirow{4}{*}{ Fluazifop-p-butyl + Fomesafen } & Cyperus rotundus $\mathrm{L}$. & 52.78 & 20.77 & 40.00 & 82.39 & 47.72 \\
\hline & Oxalis latifolia & 172.22 & 67.76 & 40.00 & 9.97 & 39.24 \\
\hline & Panicum maximum Jacq. & 22.22 & 8.74 & 10.00 & 5.68 & 8.14 \\
\hline & Other species & 6.94 & 2.73 & 10.00 & 1.96 & 4.90 \\
\hline
\end{tabular}

Other species - Portulaca oleracea, Nicandra physalodes. 
Herbicide weed...

The evaluation performed 30 days after herbicide application showed an increase in 50\% of the number of species (18 species; Table 2) in comparison to the first evaluation (12 species; Table $1)$. The action of herbicide is specific to weed control, reducing the number of determined species, leading to a decline in the number of the individual species per area unit. On the other hand, the decrease in weed plants exposes the seed bank allowing them to germinate and replace the weeds that were controlled by the herbicides (BAKER, 1989).

When Bentazon was applied, the species with greater IR were Oxalis latifolia and Jaegeria hirta (Table 2). The species from the class dicotyledonous that were not controlled by Bentazon might present tolerance to this herbicide. On the other side, the lower number of species and density (De.R) were verified when the mix of fluazifop-p-butyl + Fomesafen was applied (Table 2 ). The action spectrum of this mix can control mostly monocotyledonous and dicotyledonous weeds (SILVA; FERREIRA; FERREIRA, 2007). The weed Cyperus rotundus had the highest IR and therefore it is necessary to find an herbicide specific for this weed. In addition, it is a species with a high capacity for vegetative reproduction (LIMA; BARBOSA; SILVA, 2012), making its control even more difficult. Oxalis latifolia was another weed with some tolerance to fluazifop-p-butyl +
SOUZA et al.

Fomesafen because it was present after herbicide application.

The species vary throughout the crop cycle due to the changes they cause to the environment and to the management practices that are adopted (MARQUES; SILVA; LOPES, 2011). The study of weeds present in the crop is important, since its identification, frequency, and density are part of an appropriate weed control management (OLIVEIRA; FREITAS, 2008), besides that, the dominancy of weed plants in the field must be considered to select the specific herbicide to control them (RONCHI; SERRANO; SILVA, 2010).

In relation to euditotyledonous weed species control (Table 3), the herbicides Fomesafem and the mix of Fluazifop-p-butyl + Fomesafen were efficient in controlling weeds at 7 and 14 DAA and is similar to the treatment with weeding. The efficiency decreased from 21 DAA, probably due to the germination of seeds available in the soil. The Bentazon treatment at 7 DAA did not present satisfactory results, and at $14 \mathrm{DAA}$, there was an increase in the percentage of control until the last evaluation (28 DAA). Fluazifop-p-butyl had no efficacy in the control of eudicots, due to its graminicidal action. Therefore, it was verified that the efficacy of the Fluazifop-p-butyl + Fomesafen mixture in the control of eudycot weeds is due to Fomesafen.

Table 3. Per cent control of eudicotyledonous weed plants (FL) after herbicide application (DAA).

\begin{tabular}{lllll}
\hline Treatment & 7 DAA & 14 DAA & 21 DAA & 28 DAA \\
\hline Without weeding & $0.00 \mathrm{c}$ & $0.00 \mathrm{c}$ & $0.00 \mathrm{e}$ & $0.00 \mathrm{c}$ \\
With weeding & $100.00 \mathrm{a}$ & $100.00 \mathrm{a}$ & $100.00 \mathrm{a}$ & $100.00 \mathrm{a}$ \\
Bentazon & $51.75 \mathrm{~b}$ & $62.50 \mathrm{~b}$ & $80.00 \mathrm{c}$ & $82.50 \mathrm{~b}$ \\
Fluazifop-p-butyl & $3.75 \mathrm{c}$ & $12.50 \mathrm{c}$ & $10.00 \mathrm{~d}$ & $10.00 \mathrm{c}$ \\
Fomesafen & $82.50 \mathrm{ab}$ & $77.50 \mathrm{ab}$ & $87.50 \mathrm{~b}$ & $82.50 \mathrm{~b}$ \\
Fluazifop-p-butyl + Fomesafen & $90.00 \mathrm{a}$ & $88.75 \mathrm{ab}$ & $83.75 \mathrm{bc}$ & $72.50 \mathrm{~b}$ \\
\hline DMS & 35.37 & 35.92 & 5.1 & 11.55 \\
CV $(\%)$ & 28.16 & 27.49 & 3.69 & 8.68 \\
\hline
\end{tabular}

Means followed by the same letter in the column do not differ by Tukey test $(p \leq 0.05)$.

Eudicotyledonous species - Oxalis latifólia, Jaegeria hirta, Galinsoga quadriradiata, Axonopus affinis, Commelina benghalensis, Bidens pilosa, Euphorbia irta L., Emilia sonchifolia, and Phyllanthus tenellus

Monocotyledonous weeds were controlled by the Fluazifop-p-butyl + Fomesafen mixture with an efficiency of $85 \%$, which was statistically equal to the weeding (Table 4) for up to 14 DAA. After 21 DAA, there was a decrease in the efficacy of the control $(80 \%)$, which was no longer statistically the same. The decrease in the percentage of control is also due to the germination of seeds in the soil, increasing the plant stand in the plots. Bentazon did not present satisfactory results, with the per cent of control in about $20 \%$. On the other hand, Fluazifopp-butyl increased the percentage of control similar to the weeding after 14 DAA. This increase in the control of monocotyledonous weeds is due to the fact that the herbicide acts on the growth points of the plant, ceasing it moments after its application. However, the death of the vegetable is a slow process (SILVA; FERREIRA; FERREIRA, 2007). 
Table 4. Per cent control of monocotyledonous weed plants (FL) after herbicide application (DAA).

\begin{tabular}{lllll}
\hline Treatment & $7 \mathrm{DAA}$ & $14 \mathrm{DAA}$ & $21 \mathrm{DAA}$ & $28 \mathrm{DAA}$ \\
\hline Without weeding & $0.00 \mathrm{c}$ & $0.00 \mathrm{~b}$ & $0.00 \mathrm{c}$ & $0.00 \mathrm{~d}$ \\
With weeding & $100.00 \mathrm{a}$ & $100.00 \mathrm{a}$ & $100.00 \mathrm{a}$ & $100.00 \mathrm{a}$ \\
Bentazon & $11.25 \mathrm{c}$ & $25.00 \mathrm{~b}$ & $10.00 \mathrm{c}$ & $6.25 \mathrm{~cd}$ \\
Fluazifop-p-butyl & $56.25 \mathrm{~b}$ & $88.75 \mathrm{a}$ & $87.50 \mathrm{ab}$ & $85.00 \mathrm{ab}$ \\
Fomesafen & $43.75 \mathrm{~b}$ & $18.75 \mathrm{~b}$ & $22.50 \mathrm{c}$ & $16.25 \mathrm{c}$ \\
Fluazifop-p-butyl + Fomesafen & $88.75 \mathrm{a}$ & $86.25 \mathrm{a}$ & $80.00 \mathrm{~b}$ & $76.25 \mathrm{~b}$ \\
\hline DMS & 21.93 & 40.11 & 19.25 & 16.6 \\
CV $(\%)$ & 19.09 & 32.86 & 17.72 & 14.45 \\
\hline
\end{tabular}

Means followed by the same letter in the column do not differ by Tukey test $(p \leq 0.05)$.

For total weed control (Table 5), the mixture between Fluazifop-p-butyl + Fomesafen, evaluated at 7 and 14 DAA, showed similar control as the weeding one. After $21 \mathrm{DAA}$, the control of weeds decreased $(70 \%)$ due to the appearance of new plants. The highest control efficacy of the Fluazifopp-butyl + Fomesafen blend in all evaluations was due to the action spectrum provided by these two herbicides, which encompasses the control of monocotyledonous and eudetotyledoneous species.
Bentazon, Fluazifop-p-butyl, and Fomesafen alone did not present satisfactory results in all evaluations. The low efficacy of these herbicides for total weed control is due to the action spectrum, being selective for a certain set of weeds (OLIVERIA JÚNIOR, 2011), and not controlling the species of this spectrum. Similar results were observed by Fontes, Oliveira and Gonçalves (2013) with Fluazifop-pbutyl + Fomesafem in BRS Guariba cowpea.

Table 5. Total per cent control of weed plants (FL) after herbicide application (DAA).

\begin{tabular}{lllll}
\hline Treatment & 7 DAA & 14 DAA & 21 DAA & 28 DAA \\
\hline Without weeding & $0.00 \mathrm{~d}$ & $0.00 \mathrm{c}$ & $0.00 \mathrm{~d}$ & $0.00 \mathrm{~d}$ \\
With weeding & $100.00 \mathrm{a}$ & $100.00 \mathrm{a}$ & $100.00 \mathrm{a}$ & $100.00 \mathrm{a}$ \\
Bentazon & $25.00 \mathrm{c}$ & $38.75 \mathrm{~b}$ & $26.25 \mathrm{c}$ & $10.00 \mathrm{dc}$ \\
Fluazifop-p-butyl & $33.75 \mathrm{bc}$ & $45.00 \mathrm{~b}$ & $35.00 \mathrm{c}$ & $30.00 \mathrm{c}$ \\
Fomesafen & $48.75 \mathrm{~b}$ & $33.75 \mathrm{~b}$ & $26.25 \mathrm{c}$ & $22.50 \mathrm{c}$ \\
Fluazifop-p-butyl + Fomesafen & $87.50 \mathrm{a}$ & $86.25 \mathrm{a}$ & $70.00 \mathrm{~b}$ & $72.50 \mathrm{~b}$ \\
\hline DMS & 23.51 & 17.24 & 25.75 & 20.55 \\
CV $(\%)$ & 20.81 & 14.82 & 26.11 & 22.84 \\
\hline
\end{tabular}

Means followed by the same letter in the column do not differ by Tukey test $(p \leq 0.05)$.

The phytotoxicity in cowpea plants (Figure 1) was also observed in all evaluations and all herbicides used in cowpea. Although Fluazifop-pbutyl did not initially cause cowpea intoxication, the effect of this herbicide was observed slightly in the evaluations performed at 14 and $21 \mathrm{DAA}$ and was no longer verified at 28 DAA. Bentazon caused mild intoxication to cowpea, with evident effects at 7, 14, and 21 DAA. Fomesafen caused severe intoxication in cowpea at $7 \mathrm{DAA}$, and then decreasing throughout the evaluations. Similar phenomena were observed with the Fluazifop-pbutyl + Fomesafen mixture.

Phytotoxicity caused by the Fluazifop-pbutyl + Fomesafen mixture can be attributed to Fomesafen since Fluazifop-p-butyl alone did not cause serious damage to cowpea (Figure 1). In plants receiving Fomesafen and Fluazifop-p-butyl + Fomesafen, symptoms of intoxication could be observed approximately 3 hours after application.
The symptoms consisted of moist-looking patches due to extravasation of fluid into the extracellular space. These spots evolved giving rise to foliar tissue necrosis (SILVA; FERREIRA; FERREIRA, 2007). This herbicide acts through contact action (OLIVEIRA JUNIOR, 2011), and is influenced by the size and formation of gout, which will determine the damage to the foliar tissue.

Linhares, Freitas and Silva (2014) also reported alterations to the growth of cowpea under the effect of the herbicides Fomesafen and Bentazon + Imazamox, where Fomesafen caused severe phytotoxicity in plants evaluated 3 and 9 DAA, though regressing to an average phytotoxification at 15 DAA, and at 20 DAA occurred in the cowpea plants. Similar results were found by Oliveira, Alves and Teixeira (2013), where Fomesafen provided high phytotoxicity to cowpea plants, compromising its development. 


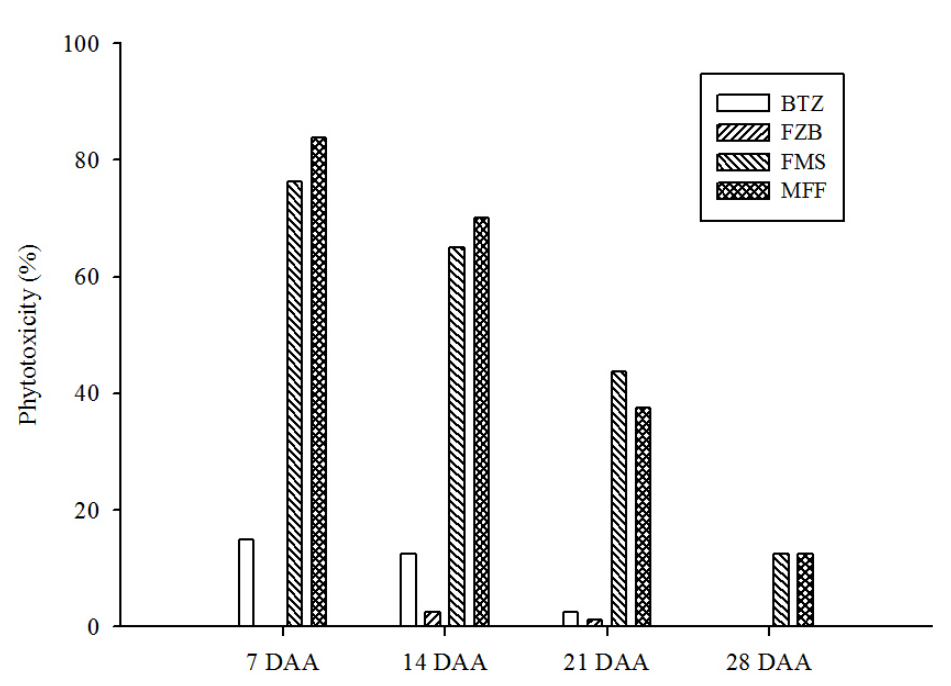

Figure 1. Phytotoxicity in cowpea plants subjected to herbicides. Bentazon (BTZ), Fluazifop-p-butyl (FZB), Fomesafen (FMS), and Fluazifop-p-butyl + Fomesafen (MFF) at 7, 14, 21, and 28 days.

Means followed by the same letter in each evaluation date do not differ by Tukey test $(p \leq 0.05)$

The herbicides caused a reduction in leaf area and dry matter content in cowpea plants evaluated at 20 DAA (Table 6). These alterations may be due to competition with weeds, as in the case of Bentazon and Fluazifop-p-butyl, which did not result in efficient weed control (Tables 2-5). In plants subjected to Fomesafen, in addition to competition with monocotyledon species (Table 4), the phytotoxic effect of the herbicide was added, causing foliar tissue necrosis (Figure 1) and growth reduction. When Fluazifop-p-butyl + Fomesafen were used, the reductions in dry mass and leaf area of cowpea were attributed to herbicide phytotoxicity to the plants.

Table 6. Leaf area (AF) and dry mass (DM), of cowpea plants.

\begin{tabular}{lll}
\hline Treatment & $\mathrm{AF}\left(\mathrm{cm}^{2}\right)$ & $\mathrm{DM}(\mathrm{g})$ \\
\hline Without weeding & $1416.80 \mathrm{~b}$ & $15.98 \mathrm{bc}$ \\
With weeding & $3554.96 \mathrm{a}$ & $29.16 \mathrm{a}$ \\
Bentazon & $1496.83 \mathrm{~b}$ & $14.28 \mathrm{bcd}$ \\
Fluazifop-p-butyl & $1811.92 \mathrm{~b}$ & $18.63 \mathrm{~b}$ \\
Fomesafen & $778.38 \mathrm{~b}$ & $5.77 \mathrm{~d}$ \\
Fluazifop-p-butyl + Fomesafen & $933.76 \mathrm{~b}$ & $7.12 \mathrm{cb}$ \\
\hline DMS & 1616.8 & 9.30 \\
CV $(\%)$ & 42.24 & 23.09 \\
\hline
\end{tabular}

Means followed by the same letter in the column do not differ by Tukey test $(p \leq 0.05)$.

The evaluation of leaf area and dry mass was carried out with the plants under stress as a function of intoxication caused by herbicides. In these cases, detoxification mechanisms are activated to convert the active ingredient into less toxic or non-toxic compounds into their metabolism through energy-consuming processes that cause plant growth to be halted and reducing dry mass accumulation (OGLIARI; FREITAS; EVARISTO, 2014). Fomesafen is also reported to cause reductions in growth due to alterations in leaf area and dry mass in cowpea plants (LINHARES; FREITAS; SILVA, 2014).
The effects of Fomeafen on growth are extended due to its influence on the induction of the fall of the leaf (FONTES; OLIVEIRA; GONÇALVES, 2013), which leads to a reduction in the productivity of the crop (IBRAHIM; AUWALU; UDOM, 2010; MONDAL; FAKIR; ISMAIL, 2011). These effects are also reported in plants influenced by the herbicides Fluazifop-p-butyl, Fomesafen, and Fluazifop-p-butyl + Fomesafen (MONTEIRO; CHAGAS JUNIOR; REIS, 2012). Similarly, in our experiment, the herbicides Fluazifop-p-butyl, Fomesafen, and Fluazifop-p-butyl + Fomesafen caused reductions in the dry mass of cowpea with 
greater effects when Fomesafen and Fluazifop-pbutyl + Fomesafen were applied.

Regarding the productivity parameters, the herbicides caused reductions in the evaluated parameters, except for the number of grains per pod and weight of 100 grains (Table 7). Bentazon and Fluazifop-p-butyl resulted in the greatest reduction in the number of pods per plant, followed by Fomesafen. No differences were observed in the weeding control and the mixture Fluazifop-p-butyl + Fomesafen. Similar effects were found by Linhares, Freitas and Silva (2014) when evaluating the effects of herbicides on the components of cowpea productivity.

Table 7. Number of grains per pod (NGP), weight of 100 grains (WG), number of pods per plant (NPP), length of the pods (LP), and crop productivity (PROD) $\mathrm{kg}$. ha ${ }^{-1}$ of cowpea.

\begin{tabular}{llllll}
\hline Treatment & NGP & WG & NPP & LP & PROD \\
\hline Without weeding & $7.94^{\mathrm{ns}}$ & $15.43^{\mathrm{ns}}$ & $9.57 \mathrm{a}$ & $15.22 \mathrm{ab}$ & $256 \mathrm{~b}$ \\
With weeding & 8.95 & 15.39 & $3.37 \mathrm{c}$ & $16.42 \mathrm{a}$ & $731.18 \mathrm{a}$ \\
Bentazon $\left(720 \mathrm{~g} \mathrm{ha}^{-1}\right)$ & 7.97 & 14.77 & $2.87 \mathrm{c}$ & $14.54 \mathrm{ab}$ & $306.31 \mathrm{~b}$ \\
Fluazifop-p-butyl $\left(250 \mathrm{~g} \mathrm{ha}^{-1}\right)$ & 9.09 & 14.93 & $6.97 \mathrm{ab}$ & $15.86 \mathrm{ab}$ & $502.72 \mathrm{ab}$ \\
Fomesafen $\left(187,5 \mathrm{~g} \mathrm{ha}^{-1}\right)$ & 7.67 & 14.77 & $4.12 \mathrm{bc}$ & $14.42 \mathrm{~b}$ & $190.23 \mathrm{~b}$ \\
Fluazifop-p-butyl+fomesafen $\left(250 \mathrm{~g} \mathrm{ha}^{-1}+187,5 \mathrm{~g} \mathrm{ha}^{-1}\right)$ & 8.83 & 14.53 & $7.77 \mathrm{a}$ & $15.76 \mathrm{ab}$ & $492.4 \mathrm{ab}$ \\
\hline CV\% & 11.63 & 6.69 & 23.11 & 5.65 & 7.43 \\
DMS & 2.24 & 2.3 & 3.07 & 1.99 & 411.11 \\
\hline
\end{tabular}

Means followed by the same letter in the column do not differ by Tukey test $(p \leq 0.05)$. NS $=$ Not significant.

The length of pods also suffered reductions, with lower averages caused by Fomesafen (Table 7). The reduction of the number of pods per plant is due to the stress caused by the application of the herbicides or the effects of competition with weeds, which causes a reduction in cowpea productive potential, leading the plants to produce smaller pods when compared to cowpea plants without competition weeds (FONTES; OLIVEIRA; GONÇALVES, 2013).

The yield of the crop was affected by herbicide use (Table 7), with herbicides Bentazon and Fomesafen, which yielded lower yield values. These herbicides expressed a low control of the weed species present in the area (Tables 2 and 5). In addition to reduced productivity, low weed control, and phytotoxicity, Fomesafen also caused an increase in the productive cycle at 15 DAA.

Fluazifop-p-butyl and the Fluazifop-p-butyl + Fomesafen mixture provided higher yields. Fluazifop-p-butyl efficiently controlled Panicum maximum, which prior to the application of the herbicide was the one that most competed with the cowpea (Table 2), thus reducing the interspecific competition for environmental resources, and allowing cowpea to better express its productive potential. Although the mix of Fluazifop-p-butyl + Fomesafen caused phytotoxicity initially, the herbicide controlled the weeds (Tables 2, 3, 4 and 5), which was favourable to the cowpea and allowed it to increase in productivity gains after recovering from the phytotoxicity. The use of the Fluazifop-p-butyl + Fomesafen mixture, as well as Fomesafen, caused an increase in the productive cycle at 15 DAA, which can be harmful to the crop as it may cause a higher incidence of pests and diseases.

In a study conducted by Fontes, Oliveira and Gonçalves (2013), the competition of cowpea with weeds led to a reduction in yield of $42 \%$ when compared to weeding control. In the same work, the authors reported the effect of the Fomesafen herbicide and the Fluazifop-p-butyl + Fomesafen mixture. Fomesafen action caused intense defoliation in cowpea besides prolonging the flowering time of the crop and reducing $38 \%$ of the yield when compared to weeding control. The yield of plants subjected to Bentazon and Fluazifop-pbutyl was similar to the weeding control, differing from the results presented in the present study.

Similar results of reduced productivity of cowpea by application of Fomesafen were reported by Oliveira, Alves and Teixeira (2013) and Linhares, Freitas and Silva (2014). Besides the reduction of productivity, they verified a delay in the harvest of 13 days. Silva, Freitas and Silveira (2014) evaluated the effects of Fomesafen, the mixture of fluazifop p-butyl + Fomesafen, and Fluazifop-p-butyl in the productivity of BRS Guariba cowpea, and concluded that Fomesafen and the Fluazifop-p-butyl + Fomesafen mixture caused a decrease in productivity.

\section{CONCLUSIONS}

The species Oxalis latifolia represents an important weed problem in cowpea cultivation 
once this weed is not easily controlled by the test herbicides.

Fomesafen applied alone, and in mixture with Fluazifop-p-butyl, caused prolongation in the productive cycle. However, Fluazifop-p-butyl + Fomesafen provided efficient control of several weed species. Cowpea shows differential tolerance by responding differently to the tested herbicides.

\section{ACKNOWLEDGMENTS}

This study was financed in part by the Coordenação de Aperfeiçoamento de Pessoal de Nível Superior- Brasil (CAPES)- Finance Code 001.

RESUMO: O uso de herbicidas é uma alternativa promissora, pois permite um controle eficiente da população de plantas infestantes, associado a baixo custo operacional e sem exigir grandes quantidades de mão de obra. No entanto, um entrave no controle de plantas daninhas no feijão-caupi é a ausência de herbicidas registrados para essa cultura. Objetivou-se com este trabalho avaliar a tolerância do feijão-caupi cultivar BRS Guariba, a herbicidas. Um ensaio foi conduzido a campo em blocos casualizados composto dos tratamentos, testemunhas com e sem capina, Bentazon (720 g i.a. ha $\left.{ }^{-1}\right)$, Fluazifop-p-butyl (250 g i.a. ha $\left.{ }^{-1}\right)$, Fomesafen (187,5 g i.a. ha $\left.{ }^{-1}\right)$ e mistura de tanque entre Fluazifop-p-butyl + Fomesafen $\left(250+187,5\right.$ g i.a. ha $\left.{ }^{-1}\right)$ com 4 repetições. Os herbicidas foram aplicados com plantas de caupi em estágio vegetativo $\mathrm{V}_{3}$ com pulverizador costal pressurizado por $\mathrm{CO}_{2}$ com quatro pontas de pulverização TT 110.02 operando a uma pressão de 2,5 Bar e aplicando $240 \mathrm{~L} \mathrm{ha}^{-1}$ de calda. As parcelas foram compostas 5 linhas de plantio com cinco metros de comprimento, espaçadas de $0,5 \mathrm{~m}$, com as 3 linhas centrais de área útil, desprezando $0,5 \mathrm{~m}$ das extremidades. Avaliou-se a comunidade infestante, a eficiência de controle de plantas daninhas, a tolerância e a produtividade do feijão-caupi. A espécie Oxalis latifolia foi encontrada em todos os tratamentos e apresentou difícil controle. A mistura Fluazifop-p-butyl + Fomesafen apresentou melhor controle das plantas daninhas. Os herbicidas ocasionaram fitotoxicidade ao feijão-caupi e redução de área foliar e massa seca de plantas. A produtividade da cultura foi reduzida nos tratamentos com baixo controle de plantas daninhas bem como nos tratamentos que provocaram toxicidade elevada. Conclui-se que o feijão-caupi apresentou tolerância diferencial aos herbicidas nas doses testadas.

PALAVRAS-CHAVE: Controle químico. Tolerância a herbicidas. Produtividade. Vigna unguiculata.

\section{REFERENCES}

BAKER, H. G. Some aspects of the natural history of seed banks. In: LECK, M. A.; PARKER, V. T.; SIMPSON, R. L. (Eds.). Ecology of soil seed banks. London: Academic Press, 1989. p. 5-19. https://doi.org/10.1016/B978-0-12-440405-2.50007-5

CARVALHO, L. B. Estudos ecológicos de plantas daninhas em agroecossistemas. Jaboticabal, SP, 2011, 58 p.

FAYINMINNU, O. O.; ADESIYAN, S. O.; SOSANYA, S. O. Effect of paraquat as post emergence herbicide on yield of cowpea (Vigna unguiculate (L.) Walp. Journal of Agricultural and Social Research, v. 10, p. 186-192, 2010. https://doi.org/10.4314/jasr.v10i2.67590

FONTES, J. R. A.; OLIVEIRA, I. J.; GONÇALVES, J. R. P. Seletividade e eficácia de herbicidas para cultura do feijão-caupi. Revista Brasileira de Herbicidas, v.12, n.1, p.47-55, jan./abr. 2013.

https://doi.org/10.7824/rbh.v12i1.214

FRANS, R. W. Measuring plant response. In: WILKINSON, R. E. (Ed.). Research methods in weed science. Puerto Rico: Weed Science Society of America, Southern Weed Science Society, 1972. p. 28-41

FREIRE FILHO, V. Q.; ROCHA, M. M.; SILVA, K. J. D. Feijão-caupi no Brasil: produção, melhoramento genético, avanços e desafios. Teresina: Embrapa Meio-Norte, 2011. 84 p. 
FREITAS, F. C. L.; MEDEIROS, V. F. L. P.; GRANGEIRO, L. C. Interferência de plantas daninhas na cultura do feijão-caupi. Planta Daninha, Viçosa, v. 27, n. 2, p. 241-247, 2009. https://doi.org/10.1590/S010083582009000200005

FREITAS, A.C. R. A importância econômica do feijão-caupi. 2005-2011. EMBRAPA. Acesso em 08 de junho, 2016. Disponível em:

http://www.agencia.cnptia.embrapa.br/gestor/feijaocaupi/arvore/CONTAG01_14_510200683536.html

GARKO, M. S.; MOHAMMED, I. B.; FULANI, M. S. Performance of cowpea (Vigna unguiculata L. Walp) varieties as influenced by weed control treatment in the Sudan Savanna of Nigeria. International Journal of Scientific and Research Publications, v. 6, p. 134-140, 2016.

HALL, A. E. Phenotyping cowpeas for adaptation to drought. Frontiers in Physiology, v. 3, p. 155, 2012. https://doi.org/10.3389/fphys.2012.00155

IBRAHIM, U.; AUWALU, B. M.; UDOM, G. N. Effect of stage and intensity of defoliation on the performance of vegetable cowpea (Vigna unguiculata) (L.) Walp). World Journal of Agricultural Sciences, v.6, n.4, p.460-465, 2010.

INMET: Instituto Nacional de Meteorologia. Consulta Dados da Estação Automática: Seropédica - Ecologia Agrícola (RJ) Diponivel em < http://www.inmet.gov.br/sonabra/pg_dspDadosCodigo_sim.php?QTYwMQ>. Acesso em 10 de fevereiro de 2017. Dados referentes à 2015.

LIMA, L. K. S.; BARBOSA, A. J. S.; SILVA, R. T. L. Distribuição fitossociológica da comunidade de plantas espontâneas na bananicultura. Revista Verde. v. 7, p. 59-68, 2012.

LINHARES, C. M. S.; FREITAS, F. C. L.; SILVA, K. S. Crescimento do feijão-caupi sob efeito dos herbicidas fomesafen e bentazon+imazamox. Revista Caatinga, Mossoró, v. 27, n. 1, p. 41-49, 2014

MARQUES, L. J. P.; SILVA, M. R. M.; LOPES, G. S. Dinâmica de populações e fitossociologia de plantas daninhas no cultivo do feijão-caupi e mandioca no sistema corte e queima com o uso de arado. Planta Daninha, Viçosa, v. 29, p. 981-989, 2011. https://doi.org/10.1590/S0100-83582011000500004

MESQUITA, H. C.; FREITAS, F. C. L.; FREIRE FILHO, F. R. Eficácia e seletividade de herbicidas em cultivares de feijão-caupi. Revista Brasileira de Herbicidas, v.16, n.1, p.50-59, jan./mar. 2017. https://doi.org/10.7824/rbh.v16i1.505

MONDAL, M. M. A.; FAKIR, M. S. A.; ISMAIL, M. R. Effect of defoliation on growth, reproductive characters and yield in mungbean [Vigna radiata (L.) Wilczek]. Australian Journal of Crop Science, v.5, n.8, p.987-992, 2011.

MONTEIRO, F. P. R.; CHAGAS JUNIOR, A. F.; REIS, M. R. Efeitos de herbicidas na biomassa e nodulação do feijão-caupi inoculado com rizóbio. Revista Caatinga, v. 25, p. 44-51, 2012.

OGLIARI, J.; FREITAS, S. P.; EVARISTO, J. A. E.; et al. Análise do perfil eletroforético de proteínas citoplasmáticas para verificação do processo de desintoxicação do herbicida mesotrione em plantas de Zea mays. Planta Daninha, Viçosa, v. 32, n. 1, p. 161-172, 2014. https://doi.org/10.1590/S010083582014000100018

OLIVEIRA JUNIOR, R. S. Introdução ao controle químico. In OLIVEIRA JUNIOR, R. S.; CONSTANTIN, J.; INOUE, M. H. Biologia e manejo de plantas daninhas. Curitiba, PR: Omnipax, 2011. 348 p.

OLIVEIRA, A. R.; FREITAS, S. P. Levantamento fitossociológico de plantas daninhas em áreas de produção de cana-de-açúcar. Planta Daninha, v. 26, n. 1, p. 33-46, 2008. https://doi.org/10.1590/S010083582008000100004 . 
OLIVEIRA, M. B.; ALVES, P. F. S.; TEIXEIRA, M. F. F. Fitotoxicidade de herbicidas aplicados em diferentes épocas em pós-emergência do feijão-caupi. Unimontes Cientifica, Montes Claros, v. 15, n. 1, 2013.

PADULOSI, S.; NG, .N. Q. Origin, Taxonomy, and morphology of Vigna unguiculata (L.) Walp. In. SING, B. B.; MOHAN RAJ, D. R.; DASHIEL, K. E.; JACKAI, L. E. N. (Ed.) Advances in cowpea research. Ibadan: IITA-JIRCAS, 1997. p. 1-11.

RONCHI, C. P.; SERRANO, L. A. L.; SILVA. A. A. Manejo de plantas daninhas na cultura do tomateiro. Planta Daninha, Viçosa, v. 28, n. 1, p. 215-228, 2010. https://doi.org/10.1590/S0100-83582010000100025

SILVA, A. A.; FERREIRA, F. A.; FERREIRA, L. N. Herbicidas: classificação e mecanismos de ação. In: SILVA, A. A.; SILVA, J. F. Tópicos em manejo de plantas daninhas. UFV: Viçosa, 2007. 367 p.

SILVA, K. S.; FREITAS, F. C. L.; SILVEIRA, L. M. Eficiência de herbicidas para a cultura do feijão-caupi. Planta Daninha, Viçosa, v. 32, n. 1, p. 197-205, 2014. https://doi.org/10.1590/S0100-83582014000100022

SIMPLÍCIO, S. F.; GONÇALVES, A. C. M.; DUARTE, E. C. C. Características de crescimento e produção do feijão-caupi (Vigna unguiculata L. Walp.) sob aplicação de herbicidas. Revista AGROTEC, v. 37, n. 1, p. 5562, 2016.

SIZENANDO FILHO, F. A.; ALMEIDA, E. I. B.; PINTO, C. M. Seletividade de Diferentes Herbicidas ao Feijão-caupi. Revista Brasileira de Agropecuária Sustentável, v.3, n.2, p.84-90, 2013. 